\title{
DISTRIBUSI DAN KELIMPAHAN FITOPLANKTON YANG BERPOTENSI MENYEBABKAN HABS (HARMFUL ALGAL BLOOMS) DI MUARASUNGAI BANJIR KANAL TIMUR, SEMARANG
}

\author{
Distribution and Abundance of Potentially Phytoplankton Which EffectHABs \\ (Harmful Algal Blooms) in The Banjir Kanal Timur Estuary, Semarang
}

\section{Erna Agustin Nurcahyani, Sahala Hutabarat*), Bambang Sulardiono}

Program Studi Manajemen Sumberdaya Perairan, Jurusan Perikanan Fakultas Perikanan dan Ilmu Kelautan, Universitas Diponegoro

J1. Prof. Soedarto, SH, Tembalang, Semarang, Jawa Tengah - 50275, Telp/Fax +6224 7474698

Email : ernaagustinc@yahoo.co.id

\begin{abstract}
ABSTRAK
Aktivitas yang ada di aliran Sungai Banjir Kanal Timur seperti industri dan pemukiman pendudukdiduga memberi kontribusi suplai zat hara di daerah muara yang dapat memicubloomingfitoplankton dan menurunkan kualitas perairan. Tujuan penelitian ini adalahuntuk mengetahui jenis fitoplankton yang berpotensi menyebabkan HABs serta distribusi spasiotemporal dan kelimpahannya berdasarkan pasang surut. Metode yang digunakan dalam penelitian ini adalah metode studi kasus yang bersifat deskriptif dengan teknik pengambilan sampelpurposive sampling. Pengambilan sampel berdasarkan aktivitas yang ada di muara dilakukan di 4 titik sampling yaitu titik I area mangrove dan tambak, titik II area pertemuan dua sungai, titik III dan IV area pantai yang menjadi jalur transportasi nelayan. Sampel diambil empat hari sekali selama tiga kali ulangan. Fitoplankton yang teridentifikasi terdiri dari 4 kelas 24 genus, 4 genus diantaranya termasuk dalam kelompok penyebab HABs yaitu Skeletonema sp. dengan kelimpahan (765-1911 Ind/L saat pasang, 233-574 Ind/L saat surut), Trichodesmium sp. (785-1678 Ind/L saat pasang, 764-1168 Ind/L saat surut), Pseudonitzschia sp. (127-191 Ind/L saat pasang, 0-84 Ind/L saat surut) dan Ceratium sp. (0-63 Ind/L saat pasang, 0-42 Ind/L saat surut). Skeletonema sp. dengan pola penyebaran seragam dan Trichodesmium sp. dengan pola penyebaran mengelompok dominan ditemukan di keempat titik sampling saat pasang dan surut, sedangkan Pseudonitzschia sp. dengan pola penyebaran mengelompok terdapat di semua titik saat pasang sedangkan saat surut terdapat di titik II, III dan IV. Ceratium sp. dengan pola penyebaran seragam terdapat di titik I dan IV saat pasang, serta terdapat di titik III dan IV saat surut.
\end{abstract}

Kata kunci : Kelimpahan Fitoplankton; Distribusi; Harmful Algal Blooms (HABs);Pasang surut; Muara Sungai Banjir Kanal Timur

\begin{abstract}
Activities in Banjir Kanal Timur river like industry activities and settlements was expected give contribution to supply nutrient in estuary and can cause blooming of phytoplankton and decrease estuary's water quality. The aimed of this research was to determine spatiotemporal distribution and abundance of potentially phytoplankton which effect Harmful Algal Blooms (HABs) based on tidalrange. This research used case studly method (descriptive) and purposive sampling technique. Samples were takenfrom 4 stationevery four days for three replication. Station (I)in mangrove and fishpond area, station (II) in confluence of two rivers area, station III and $I V$ in the beach with boat's traffic track. Phytoplankton consisted of 4 class and 24 genus, four of them was genus HABs included Skeletonema sp. with abundance (765- 1911 ind/L at high tide, 233- 574 ind/L at low tide), Trichodesmium sp. (785- 1678 ind/L at high tide, 764- 1168 ind/L at low tide), Pseudonitzschia sp. (127$191 \mathrm{ind} / \mathrm{L}$ at high tide, $0-84 \mathrm{ind} / \mathrm{L}$ at low tide) and Ceratium sp. (0- $63 \mathrm{ind} / \mathrm{L}$ at high tide, $0-42 \mathrm{ind} / \mathrm{L}$ at low tide). Skeletonema sp. (regular distribution patterns) and Trichodesmium sp. (uniform distribution patterns) were dominant in all station at high tide or low tide. Pseudonitzschia sp.(uniform distribution patterns) was in all station at high tide andat low tide was in station II,III and IV. Ceratium sp. (regular distribution patterns) was in station I and IV at high tide, and at low tide was found in station III and IV.
\end{abstract}

\section{Keywords :Phytoplankton'sAbundance; Distribution;Harmful Algal Blooms (HABs); Tidalrange; Estuary of BanjirKanal Timur}

*) Penulis penanggungjawab 


\section{PENDAHULUAN}

Perairan muara banyak mendapat suplai zat hara dari hulu. Suplai zat hara terbawa oleh air sungai dari bagian hulu yang belum terkena aktivitas manusia hingga tengah yang telah terkena aktivitas manusia. Beberapa aktivitas yang ada di Sungai Banjir Kanal Timur menurut Wulandari (2012),meliputi industri tekstil, bahan makanan, plastik, karoseri, percetakan, farmasi dan jamu, cat, mebel, minyak pelumas, perbengkelan, bahkan terdapat tempat pelelangan ikan.Kegiatan tersebut pada umunya memberi kontribusi suplai zat hara (nitrat dan fosfat) di muara.

Nitrat $(\mathrm{N})$ dan fosfat $(\mathrm{P})$ merupakan unsur yang dibutuhkan oleh fitoplankton untuk pertumbuhan. Tingginya kadar $\mathrm{N}$ dan $\mathrm{P}$ dapat menyebabkan blooming fitoplankton yang memberi dampak penting di muara. Fitoplankton berperan sebagai produsen primer yang mampu mensintesa zat anorganik menjadi zat organik dengan bantuan cahaya dan klorofil. Blooming fitoplankton tertentu yang bersifat toksikatau kelompok HABs (Harmful Algal Blooms) justru dapat menurunkan kualitas perairan. Jenis fitoplankton toksik menurut Aunurohim et al. (2008),diantaranyaAlexandrium sp., Gymnodinium sp., dan Dinophysis sp.(Dinoflagellata) dan Pseudonitzschia sp.(Diatom).Berdasarkan hal tersebut, penelitian ini bertujuan untuk mengetahui jenis, distribusi spasiotemporal dan kelimpahan dari fitoplankton yang berpotensi menyebabkan HABs di Muara Sungai Banjir Kanal Timur, Semarang.

\section{MATERI DAN METODE PENELITIAN \\ A. MATERI PENELITIAN}

Materi yang digunakan dalam penelitian ini adalah fitoplankton dan kualitas air. Parameter yang diamati terdiri dari parameter biologi (fitoplankton), parameter penunjang fisika(suhu, kecerahan, arus) dan parameter kimia(salinitas, $\mathrm{pH}, \mathrm{DO}$, nitrat, fosfat). Alat-alat yang digunakan dalam penelitian ini adalah plankton net $25 \mu \mathrm{m}$ untuk menyaring fitoplankton, termometer air raksa untuk mengukur suhu, secchi disk untuk mengukur kecerahan, bolaarus untuk mengukur kecepatan arus, refraktometer untuk mengukur salinitas, $\mathrm{pH}$ paper untuk mengukur $\mathrm{pH}$, botol winkler untuk mengukur $\mathrm{DO}$, spektrofotometer untuk mengukur $\mathrm{N}$ dan $\mathrm{P}$.

\section{B. METODE PENELITIAN}

Metode yang digunakan adalah studi kasus yang bersifat deskriptif. Tujuan penggunaan metode ini adalah untuk mendalami suatu masalah pada waktu tertentu guna memberi gambaran secara sistematis, faktual dan akurat mengenai fakta-fakta di lapangan. Hasil yang didapat dengan metode studi kasus belum tentu berlaku pada daerah dan tempat lain walaupun obyek penelitian sama.

\section{PENENTUAN LOKASI DAN TEKNIK SAMPLING}

Empat titik sampling dipilih berdasarkan aktivitas yang ada di muara dengan pertimbangan masih adanya pengaruh pasang surut. Titik I berada diarea dekat tambak dan mangrove, titik II berada di pertemuan dua sungai (Sungai Banjir Kanal Timur dan Sungai Tenggang), titik III dan IV berada di area pantai yang digunakan sebagai jalur transportasi nelayan. Teknik pengambilan sampel yang digunakan adalah purposive sampling dengan pertimbangan sampel dapat mewakili tiap titik sampling yang diduga memiliki karakteristik berbeda karena perbedaan aktivitas.

\section{ANALISIS DATA}

Data yang diperoleh kemudian diolah untuk mengetahui kelimpahan fitoplankton, indeks fitoplankton (keanekaragaman, keseragaman, dominasi), indeks morisita dan indeks similaritas.

a.

Kelimpahan fitoplankton

Jumlah individu per liter menggunakan rumus APHA, AWWA, WPOF (1976):

$\mathrm{N}=\frac{\mathrm{T}}{\mathrm{L}} \times \frac{\mathrm{P}}{p} \times \frac{\mathrm{V}}{v} \times \frac{1}{\mathrm{w}}$

Keterangan :

$\mathrm{N}=$ Jumlah Plankton per liter

$\mathrm{T}=$ Luas gelas penutup $\left(\mathrm{mm}^{2}\right)$

$\mathrm{L}=$ Luas lapang pandang $\left(\mathrm{mm}^{2}\right)$

$\mathrm{P}=$ Jumlah fitoplakton yang tercacah

$\mathrm{p}=$ Jumlah lapang pandang yang diamati

$\mathrm{V}=$ Volume sampel plankton yang tersaring $(\mathrm{ml})$

$\mathrm{v}=$ Volume sampel plankton dibawah gelas penutup

$\mathrm{w}=$ Volume sampel plankton yang disaring (liter)

b.

\section{Indeks Keanekaragaman}

Indeks Keanekaragaman Shanon-Weaver (Odum, 1971) dirumuskan sebagai berikut :

$\mathrm{H}^{\prime \prime}=-\sum_{\mathrm{i}=1}^{\mathrm{S}} \mathrm{Pi} \operatorname{in} \mathrm{ri}$

dimana $\mathrm{Pi}=\mathrm{Ni} / \mathrm{N}$

Keterangan :

$\mathrm{H}^{\prime}=$ Indeks Keanekaragaman

$\mathrm{Ni}=$ Jumlah individu jenis ke- 1

$\mathrm{N}$ = Jumlah individu total 
c. Indeks keseragaman

Menurut Odum (1971) indeks keseragaman dapat dihitung dengan menggunakan rumus sebagai berikut: $E=\frac{\mathrm{H}^{\prime}}{\mathrm{Hmaks}}$

Hmaks $=\ln \mathrm{S}$

Keterangan :

$\mathrm{e}=$ Indeks Keseragaman

$\mathrm{S}=$ Jumlah jenis

d. Indeks dominasi

Indeks dominansi diperoleh menggunakan indeks Simpson (Odum 1971):

$\mathrm{c}=\sum_{\mathrm{i}=1}^{\infty}\left(\frac{\mathrm{ni}}{\mathrm{N}}\right)$

Keterangan:

$\mathrm{C}=$ Indeks dominansi Simpson, $\mathrm{ni}=$ Jumlah individu jenis ke-i, $\mathrm{N}=$ Jumlah total individu

e. Indeks morisita

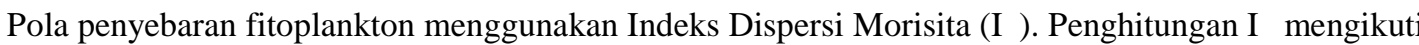
rumus Brower et al. (1990), yaitu:

$\mathrm{IO}=\mathrm{n} \frac{\sum \mathrm{X}^{2}-\mathrm{N}}{\mathrm{N}(\mathrm{N}-1)}$

Keterangan:

I $\delta=$ Indeks Dispersi Morisita

$\mathrm{n}=$ Jumlah unit pengambilan contoh

$\mathrm{N}=$ Jumlah seluruh individu organisme

$\Sigma \mathrm{X}^{2}=$ Jumlah kuadrat individu suatu stasiun

Pola sebaran fitoplankton di lokasi penelitian diduga dengan menggunakan kriteria berikut: I $\delta=1$; pola sebaran acak; I $\delta<1$; pola sebaran seragam; dan I $\delta>1$; pola sebaran berkelompok.

f. Indeks similaritas

Tingkat kesamaan komunitas dihitung menggunakan indeks similaritas Sorensen (Krebs,1978).

$s=\frac{2 C}{A+B}$

Keterangan:

$\mathrm{S}=$ Indeks similaritas

$\mathrm{A}=$ Cacah spesies pada tempat $\mathrm{A}$

$\mathrm{B}=$ Cacah spesies pada tempat $\mathrm{B}$

$\mathrm{C}=$ Cacah spesies pada tempat A maupun B

\section{HASIL DAN PEMBAHASAN}

A. Hasil

Perairan Banjir Kanal Timur adalah kawasan muara dari sistem Sungai Banjir Kanal Timur, Tambak Lorok (Kali Banger) dan Kali Tenggang. Adapun Sungai Banjir Kanal Timur melintasi Kota Semarang bagian timur yang padat pemukiman dan industri. Sungai Banjir Kanal Timur memiliki panjang 14,25 km. Perairan ini menjadi tempat pembuangan limbah hasil aktivitas industri dan domestik (Wulandari, 2012).

Terdapat beberapaaktivitas yang ada di Muara Sungai Banjir Kanal Timurdiantaranyasebagai jalur transportasi nelayan dan tempat penangkapan ikan. Terdapat pula tambak-tambak,pelabuhan, Pembangkit Listrik Tenaga Uap, serta bagan-bagan di area dekat muara. Mangrove juga banyak tumbuh di tepi muara.

\section{Kelimpahan fitoplankton, Indeks keanekaragaman, Indeks keseragaman, Indeks dominasi}

Berdasarkan hasil penelitian, ditemukan 24 genus fitoplankton baik saat pasang dan surut yang terdiri dari 4 kelas yaitu Bacillariophyceae, Cyanophyceae, Chlorophyceae dan Dinophyceae. Kelimpahan total fitoplankton saat pasang yaitu antara4.242 - 11.504 Ind/L, dan saat surut 3242 - 8058 Ind/L.Bacillariophyceae merupakan kelas yang paling mendominasi dengan persentase 50\%.Rata-rata nilai indeks keanekaragaman yang diperoleh berkisar antara 2,03 - 2,21 saat pasang dan 1,80 - 2,02 saat surut.Rata-rata nilai indeks keseragaman yang diperoleh berkisar antara $0,80-0,87$ saat pasang dan $0,68-0,82$ saat surut. Rata-rata nilaiindeks dominasi yang diperoleh berkisar antara $0,13-0,17$ saat pasang dan $0,14-0,23$ saat surut. 
Tabel 1. Kelimpahan fitoplankton, nilai indeks keanekaragaman (H'), indeks keseragaman(e) dan indeks dominansi (D) saat pasang dan surut.

\begin{tabular}{ccccc}
\hline Titik Sampling & Kelimpahan (Ind/L) & H' & e & D \\
\hline Pasang & & & & \\
I & $784-3501$ & $1,94-2,21$ & $0,74-0,88$ & $0,14-0,21$ \\
II & $1230-2951$ & $1,98-2,12$ & $0,80-0,82$ & $0,06-0,16$ \\
III & $955-2356$ & $2,19-2,23$ & $0,84-0,92$ & $0,12-0,14$ \\
IV & $1294-2696$ & $1,92-2,25$ & $0,83-0,85$ & $0,08-0,18$ \\
Surut & & & & \\
I & $869-2163$ & $1,48-1,95$ & $0,57-0,75$ & $0,17-0,29$ \\
II & $741-2269$ & $1,69-2,09$ & $0,73-0,77$ & $0,08-0,25$ \\
III & $963-2014$ & $1,72-2,12$ & $0,69-0,85$ & $0,14-0,16$ \\
IV & $679-1612$ & $1,64-2,24$ & $0,66-0,90$ & $0,12-0,18$ \\
\hline
\end{tabular}

\section{Fitoplankton yang tergolong HABs}

Berdasarkan penelitian yang telah dilakukan, ditemukan beberapa fitoplankton yang tergolong dalam kelompok Harmful Algal Blooms (HABs). Terdapat empat jenis fitoplankton yang tergolong ke dalam kelompok HABs yaitu Trichodesmium sp. (Cyanophyceae), Pseudonitzschia sp., Skeletonema sp. (Bacillariophyceae), dan Ceratium sp. (Dinophyceae.) Kelimpahan fitoplankton yang tergolong dalam kelompok HABs saat pasang surut dari sampling ke-1 sampai ke-3 tersaji pada Gambar 1.

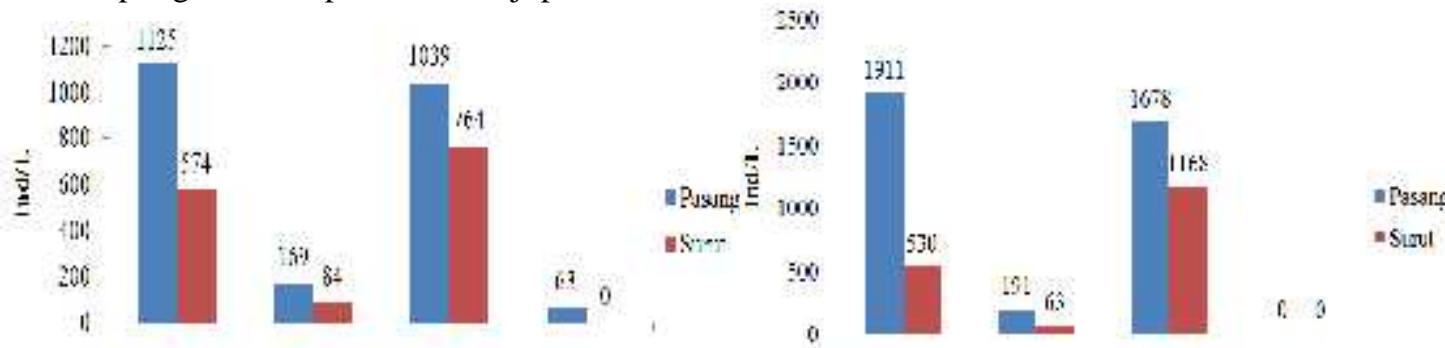

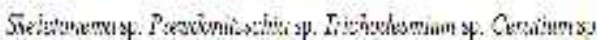
a. Sampling ke-1

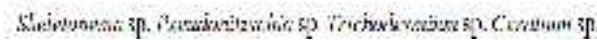

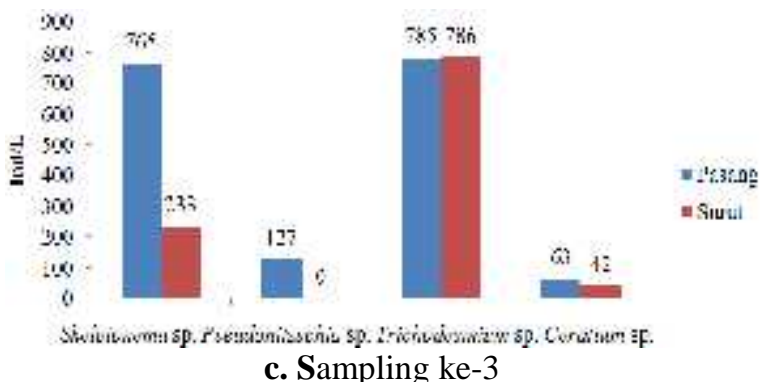

Gambar 1. Histogram Kelimpahan Fitoplankton Kelompok Penyebab HABs Selama Sampling

Kelimpahan Skeletonema sp., Pseudonitzschia sp., Trichodesmium sp.dan Ceratium sp. saat pasang sampling pertama berturut-turut yaitu 1125, 169, 1039, dan 63 Ind/L, sedangkan saat surut berturut-turut yaitu 574, 84, 764, dan 0 Ind/L. Saat sampling kedua kelimpahan Skeletonema sp., Pseudonitzschia sp., Trichodesmium sp. dan Ceratium sp.saat pasang berturut-turut yaitu 1911, 191, 1678, dan 0 Ind/L, sedangkan saat surut berturut-turut yaitu 530, 63, 1168, dan 0 Ind/L. Saat sampling ketiga kelimpahan Skeletonema sp., Pseudonitzschia sp., Trichodesmium sp. dan Ceratium sp. saat pasang berturut-turut yaitu 765, 127, 785, dan 63 Ind/L, sedangkan saat surut berturut-turut yaitu 233, 0, 786, dan 42 Ind/L.

Persentase masing-masing fitoplankton HABs dibandingkan dengan total kelimpahan fitoplankton di setiap titik sampling baik saat pasang atau surut terjsaji pada Gambar 2. 


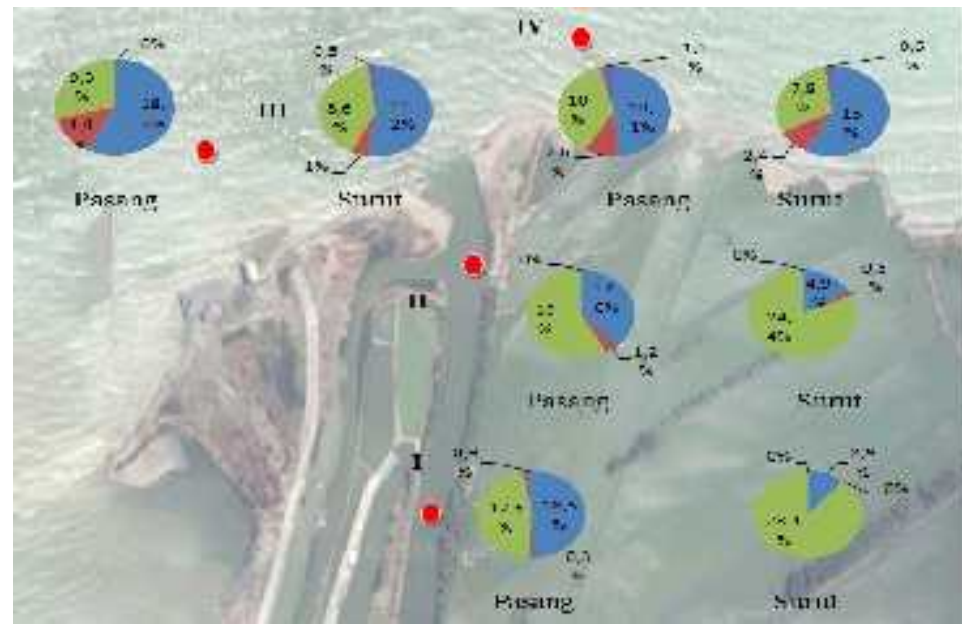

Keterangan :

Pseudonitzchia sp.

Trichodesmium sp.

Ceratium sp.

Skeletonema sp.

Gambar 2. Persentase Kelimpahan Tiap Genus Fitoplankton HABs di Setiap Titik Sampling Saat Pasang dan Surut

Persentase fitoplankton HABs tiap genus berbeda-beda nilainya saat pasang ataupun surut. Saat pasang persentase tertinggi terdapat di titik I dan terendah di titik IV. Saat surut persentase tertinggi terdapat di titik II dan terendah di titik III. Persentase tertinggi rata-rata didominasi oleh Trichodesmium sp. dan Skeletonema sp. dan terendah yaitu Ceratium sp. Berikut persentase masing-masing genus HABs dibandingkan dengan total fitoplankton HABs di lokasi penelitian saat pasang dan surut tersaji pada Gambar 3.

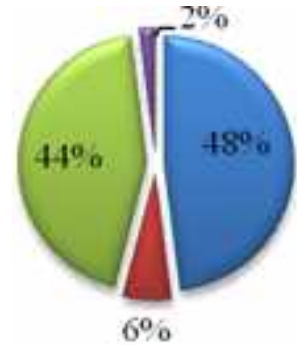

Pasang

Trichodesmium sp.

Pseudonitzschia sp.

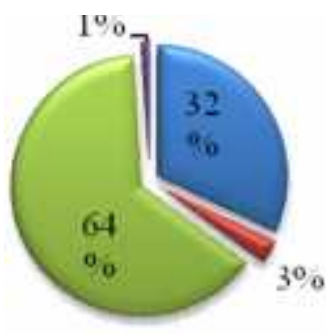

SiInit

Gambar 3. Diagram Persentase Kelimpahan Tiap Genus HABs dengan Total HABs Saat Pasang dan Surut.

Berdasarkan gambar tersebut saat pasang persentase kelimpahan tertinggi adalah Skeletonema sp. dengan persentase $48 \%$ diikuti oleh Trichodesmium sp. 44\%, Pseudonitzschia sp. 6\% dan Ceratium sp. 2\%. Persentase kelimpahan saat surut didominasi oleh Trichodesmium sp. dengan persentase 64\% lalu diikuti oleh Skeletonema sp. 32\%, Pseudonitzschia sp. 3\% dan Ceratiumsp. $1 \%$.

\section{Distribusi Fitoplankton HABs}

Trichodesmium sp. dan Skeletonema sp. rata-rata dominan ditemukan di semua titik sampling baik saat pasang maupun surut sedangkan Ceratium sp. terdapat di titik I dan IV saat pasang, serta terdapat di titik III dan IV saat surut. Pseudonitzschia sp. terdapat di semua titik saat pasang sedangkan saat surut terdapat di titik II, III dan IV.

\section{Indeks morisita}

Tabel 2. Hasil Perhitungan Indeks Distribusi Morisita Genus Fitoplankton Penyebab HABs

\begin{tabular}{lc}
\hline \multicolumn{1}{c}{ Genus } & Indeks Morisita \\
\hline Skeletonema sp. & 0,99 \\
Trichodesmium sp. & 1,18 \\
Pseudonizschia sp. & 1,07 \\
Ceratium sp. & 0,70 \\
\hline
\end{tabular}


Indeks similaritas

Tabel 3. Indeks Similaritas Antar Titik Sampling di Lokasi Penelitian.

\begin{tabular}{ccc}
\hline \multirow{2}{*}{ Titik Sampling } & \multicolumn{2}{c}{ Indeks Similaritas } \\
\cline { 2 - 3 } I dengan II & Pasang & Surut \\
\hline I dengan III & 0,89 & 0,91 \\
I dengan IV & 0,79 & 0,69 \\
II dengan III & 0,69 & 0,69 \\
II dengan IV & 0,83 & 0,74 \\
III dengan IV & 0,73 & 0,79 \\
\end{tabular}

\section{Kualitas air}

Hasil pengukuran kualitas air di Muara Sungai Banjir Kanal Timur, Semarang selama sampling ke-1 sampai sampling ke-3 baik saat pasang ataupun surut yaitu, suhu $29-34{ }^{\circ} \mathrm{C}$, kecerahan $15-41,5 \mathrm{~cm}$, kecepatan arus $0,07-0,33 \mathrm{~m} / \mathrm{s}$, DO $2,4-5 \mathrm{mg} / \mathrm{l}$, salinitas $4-26 \%$, $\mathrm{pH} 6$, nitrat $0,540-0,935 \mathrm{mg} / \mathrm{l}$ dan fosfat $0,06-0,2$ $\mathrm{mg} / \mathrm{l}$.

\section{B. Pembahasan}

\section{Kelimpahan fitoplankton, Indeks keanekaragaman, Indeks keseragaman, Indeks dominasi}

Fitoplankton yang teridentifikasi di lokasi penelitian terdiri dari 4 kelas yaitu Bacillariophyceae (12 genus), Cyanophyceae (5 genus), Chlorophyceae (6 genus), dan Dinophyceae (1 genus). Kelimpahan genus yang paling banyak ditemukan pada setiap stasiun baik saat pasang maupun surut adalah dari kelas Bacillariophyceae dengan persentase 50\%. Hal ini disebabkan karena kelas Bacillarophyceae mampu menyesuaikan diri dengan kondisi lingkungan sekitarnya. Menurut Nybakken (1992), Bacillariophyceae mampu tumbuh dengan cepat meskipun pada kondisi cahaya dan nutrien yang rendah. Hal tersebut juga dikarenakan jenis fitoplankton ini mempunyai kemampuan beradaptasi dengan baik sehingga mampu meregenerasi dan bereproduksi dalam jumlah yang lebih besar dari jenis fitoplankton yang lain. Jenis dari plankton tersebut merupakan jenis yang paling tahan terhadap perubahan lingkungan oleh pasang surut.

Kelimpahan fitoplankton tertinggi yang didapatkan dari hasil identifikasi dan perhitungan kelimpahan adalah Nitzschia sp. Genus tersebut ditemukan di semua titik sampling baik saat pasang maupun surut. Hal tersebut sesuai dengan Khaqiqoh et al. (2014), bahwa Nitzschia sp. dapat hidup dengan kondisi yang ekstrim dan mempunyai toleransi terhadap salinitas tinggi. Nitzschia sp. adalah genus dari kelas Bacillariophyceae. Menurut Sachlan (1982), Bacillariophyceae mempunyai sifat kosmopolit, tahan terhadap kondisi ekstrim, mudah beradaptasi dan mempunyai daya reproduksi yang sangat tinggi.

Nilai indeks keanekaragaman fitoplankton $\left(\mathrm{H}^{\prime}\right)$ di lokasi penelitian pada saat pasang tidak jauh berbeda di setiap titik sampling yaitu antara $1,926-2,252$. Saat surut nilai indeks keanekaragaman yaitu berkisar $1,488-$ 2,244. Secara umum keanekaragaman fitoplankton di Muara Sungai Banjir Kanal Timur Semarang termasuk stabil moderat. Menurut Stirn (1981) dalam Pirzan dan Masak (2008) apabila H' < 1, maka komunitas biota dinyatakan tidak stabil, apabila H' berkisar 1-3 maka stabilitas komunitas biota tersebut adalah moderat (sedang) dan apabila H'> 3 berarti stabilitas komunitas biota berada dalam kondisi prima (stabil).

Nilai indeks keseragaman fitoplankton (e) di lokasi penelitian pada saat pasang tidak jauh berbeda di setiap titik sampling yaitu antara $0,74-0,92$. Saat surut nilai indeks keseragaman yaitu berkisar $0,573-0,909$. Komunitas fitoplankton yang ada di Muara Banjir Kanal Timur berada pada kondisi labil hingga stabil. Menurut Yuliana (2015), fitoplankton berada dalam kondisi stabil apabila nilai yaitu antara $0,75>\mathrm{e}<1,00$. Sementara itu, nilai e antara $0,50>\mathrm{e}<0,75$ berarti bahwa komunitas fitoplankton berada pada kondisi labil.

Nilai indeks dominasi fitoplankton (C) di lokasi penelitian pada saat pasang di setiap titik sampling yaitu antara $0,082-0,218$. Saat surut nilai indeks dominasi yaitu berkisar $0,083-0,298$. Hal tersebut berarti di lokasi penelitian tidak ada spesies fitoplankton yang mendominasi karena kisaran nilai mendekati 0. Menurut Aprianti et al. (2015), jika indeks dominasi (C) mendekati nilai 1, maka ada salah satu jenis yang mendominasi jenis lain. Indeks dominasi mendekati 0 , berarti di dalam struktur komunitas biota yang diamati tidak terdapat jenis yang secara menyolok mendominasi jenis lainnya.

\section{Fitoplankton yang tergolong HABs}

Jenis yang sering ditemukan dengan kelimpahan tinggi yaitu Skeletonema sp. dan Trichodesmium sp.. Hal tersebut dikarenakan kedua jenis tersebut memiliki sifat kosmopolit dan tahan dengan kondisi ekstrim. Menurut Thoha (2004), kelompok diatom selalu dominan di setiap lokasi. Kondisi tersebut umum terjadi di perairan pesisir dan laut. Sediadi (2004), Trichodesmium sp. dijumpai di perairan laut subtropik sampai perairan laut tropik. Karakteristik Trichodesmium sp. mampu mengikat nitrogen dari udara pada saat di perairan laut yang kandungan nitratnya rendah.Menurut Aunurohim (2008), dominansi Skeletonema costatum disebabkan oleh sifatnya yang euryhaline dan eurythermal (mampu tumbuh pada kisaran suhu $3-30^{\circ} \mathrm{C}$ ), sehingga lebih toleran terhadap perubahan kondisi lingkungan. 
Persentase tertinggi kelimpahan Skeletonema sp. di lokasi penelitian adalah 18,6\% (1911 Ind/L) dari total kelimpahan fitoplankton. Kelimpahan tersebut masih tergolong rendah bila dibandingkan dengan blooming yang terjadi di Teluk Hooh Sandy, New Jersey. Menurut Gastrich (2000), blooming sedang dengan kelimpahan kirakira mencapai $10^{5} \mathrm{sel} / \mathrm{ml}$ sedangkan blooming dengan kelimpahan tinggi lebih dari $10^{6} \mathrm{sel} / \mathrm{ml}$ yang diposting oleh Algal condition report pada tahun 1999.

BloomingSkeletonema sp. perlu diwaspadaidikarenakan merupakan jenis fitoplankton HABs yang dapat menyebabkan gangguan pernapasan pada biota lain seperti ikan. Menurut Mulyani et al. (2012), Skeletonema costatum berupa koloni sel yang membentuk struktur yang memanjang, sehingga dapat menyumbat alat pernapasan pada biota laut apabila menempel di insang. Skeletonema costatum tidak menghasilkan toksin, melainkan dapat menyumbat alat pernapasan (insang) ikan atau biota lain. Hal ini diperkuat oleh GEOHAB (2001), bahwa Skeletonema costatum merupakan kelompok diatom yang dapat memberi dampak negatif berupa "hypoxia, anoxia" di perairan laut.

Kelimpahan Trichodesmium sp. mengalami fluktuasi saat pasang dan surut.Kenaikkan dan penurunan kelimpahan Trichodesmium sp. diduga disebabkan karena unsur zat hara dan suhu perairan. Menurut Adnan (1985), blooming Trichodesmium sp.di Teluk Jakarta yang awalnya diduga merupakan tumpahan minyak diikuti dengan kematian cacing, ikan dan hewan lainnya serta peningkatan suhu hingga $40^{\circ} \mathrm{C}$. Hanya bintang laut yang mampu bertahan hidup. Demikian pula pada tanggal 20 Agustus 1984 pada ekspedisi SNELIUS II di Laut Arafura dilaporkan terjadi blooming Trichodesmium sp. Pada saat itu air relatif tenang dan terlihat hamparan luas berwarna kecoklatan seperti serbuk gergaji. Dari contoh gumpalan tersebut setelah diperiksa adalah spesies Trichodesmium sp. yang mencapai kelimpahan 97,45\% dari seluruh populasi di perairan tersebut.

Keberadaan Trichodesmium sp. di perairan perlu diwaspadai karena dapat menyebabkan penurunan oksigen terlarut. Penurunan oksigen dapat membahayakan biota lain yang terdapat di perairan tersebut karena akan ada kompetisi konsumsi oksigen. Menurut Wiadnyana (1996), spesies yang menyebabkan penurunan oksigen terlarut disebut spesies "anoxious". Kelompok anoxius yang sering ditemukan adalah spesies Trichodesmium erytrhraeum, salah satu spesies dari Cyanobacterium. Penurunan oksigen drastis dapat menyebabkan kematian masal ikan dan vertebrata.

Ceratium sp. dan Pseudonitzcshia sp. hanya ditemukan dalam jumlah sedikit di lokasi penelitian. Kelimpahan Ceratium sp. berkisar antara $0-63 \mathrm{Ind} / \mathrm{L}$ saat pasang $0-42 \mathrm{Ind} / \mathrm{L}$ saat surut, sedangkan Pseudonitzschia sp. yang ditemukan berkisar antara $0-191 \mathrm{Ind} / \mathrm{L}$ saat pasang dan $0-84 \mathrm{Ind} / \mathrm{L}$ saat surut. Nilai kelimpahan tersebut masih dapat dikategorikan rendah apabila dibandingkan dengan kasus bloomingCeratium sp. yang ada di perairan bendungan Hartbeesport Afrika Selatan. Menurut Hart dan Peter (2009), bloomingCeratium sp. biasanya terjadi pada daerah dengan tingkat nutrien tinggi. Tercatat pertama kali bloomingCeratium sp. pada tahun 1999 yang terjadi secara tiba-tiba dengan kisaran kelimpahan $13.500 \mathrm{sel} / \mathrm{ml}$. Menurut GEOHAB (2001), Ceratium sp. mampu menyebabkan "hypoxia" atau dapat menurunkan kadar oksigen perairan.

Kelimpahan Pseudonitzschia sp. yang teridentifikasi di lokasi penelitian tergolong rendah. Nilai kelimpahan tidak lebih dari 191 Ind/L. BloomingPseudonitzschia sp. pernah terjadi di perairan Teluk Monterey, California. Menurut Bargu et al. (2012), Pseudonitzschiasp. selalu terdeteksi di perairan, tetapi dengan jumlah kelimpahan yang rendah yaitu kurang dari 1000 sel/L. Kelimpahan tertinggi terdeteksi pada April 2004 yang mencapai 9 x $10^{5} \mathrm{sel} / \mathrm{L}$. GEOHAB (2001) Pseudonitzschia sp. merupakan fitoplankton yang memproduksi asam domoic yang dapat menyebabkan Amnesic Shelfish Poisoning.

Blooming dari spesies fitoplankton diindikasikan dengan pertumbuhan yang pesat dan berlangsung dalam kurun waktu 1-2 minggu. Belum ada kesepakatan mengenai batasan kepadatan sel fitoplankton yang dianggap blooming yang bersifat membahayakan atau meracuni(Choirun et al., 2015).

Distribusi Fitoplankton HABs

Distribusi dari fitoplankton HABs yaitu Trichodesmium sp. dan Skeletonema sp. rata-rata terdapat di semua titik sampling baik saat pasang maupun surut. Menurut DEVASY dalam Adnan (1985), di daerah tropis ledakan populasi Trichodesmium sp.sangat sering terjadi dan dapat mencapai area yang luas. Ceratium sp. terdapat di titik I dan IV saat pasang, serta terdapat di titik III dan IV saat surut. Pseudonitzschia sp. terdapat di semua titik saat pasang sedangkan saat surut terdapat di titik II, III dan IV. Kurang meratanya distribusi Ceratium sp. dan Pseudonitzscia sp. diduga karena faktor lingkungan seperti salinitas berbeda di tiap titik sampling. Menurut Cokrowati et al. (2014), distribusi fitoplankton sangat bergantung pada lingkungan. Secara umum sangat dipengaruhi oleh suhu, salinitas dan arus.

\section{Indeks morisita}

Berdasarkan perhitungan dengan menggunakan rumus Indeks Dispersi Morisita didapatkan nilai berkisar antara 0,7 - 1,18. Pola penyebaran fitoplankton HABs di Muara Sungai Banjir Kanal Timur berdasarkan nilai tersebut adalah seragam dan mengelompok. Skeletonema sp. dan Ceratium sp. memiliki pola persebaran seragam. Trichodesmium sp. dan Pseudonitzschia sp. memiliki pola persebaran mengelompok. Menurut Isnaini (2012), bahwa nilai dispersi morisita lebih besar dari satu (Id>1) maka pola dispersi fitoplankton adalah mengelompok/ bergerombol (patchiness), kurang dari satu $(\mathrm{Id}<1)$ maka pola dispersi fitoplankton seragam. Plankton di laut umumnya tidak tersebar merata melainkan hidup secara berkelompok, berkelompoknya 
plankton lebih sering dijumpai di perairan neritik (terutama perairan yang dipengaruhi oleh estuaria) daripada perairan oseanik.

\section{Indeks similaritas}

Berdasarkan hasil perhitungan nilai indeks similaritas Sorensen, didapatkan hasil nilai indeks similaritas (kesamaan) antar stasiun di atas 69\%. Hal tersebut mengindikasikan bahwa terdapat kesamaan komunitas antar stasiun. Tingkat kesamaan antar stasiun tinggi dikarenakan mendekati 100\%. Jannah dan Muchlisin (2012), jika nilai mendekati $0 \%$ maka tingkat kemiripan rendah dan jika nilai mendekati $100 \%$ maka kesamaan komunitas antar stasiun tergolong tinggi dengan kata lain bila indeks similaritas di bawah $50 \%$ berarti komunitas fitoplankton antar stasiun berbeda, sebaliknya begitu pula sebaliknya.

\section{Kualitas air}

Suhu air yang didapatkan di daerah penelitian berkisar antara $29-34^{\circ} \mathrm{C}$ baik saat pasang maupun surut. Menurut Effendi (2003), kisaran temperatur optimum bagi pertumbuhan fitoplankton di perairan adalah 20 $30^{\circ} \mathrm{C}$. Berdasarkan hasil pengukuran, nilai DO yang didapatkan berkisar antara 2,4 - $5 \mathrm{mg} / \mathrm{l}$. Patty (2013), mengatakan bahwa tingginya kadar oksigen terlarut di perairan lepas pantai, dikarenakan airnya jernih sehingga dengan lancarnya oksigen yang masuk kedalam air tanpa hambatan melalui proses difusi dan proses fotosintesis.

Nilai kecerahan pada lokasi penelitian berkisar antara $28,5-41,5 \mathrm{~cm}$ pada saat pasang dan $15-32,5 \mathrm{~cm}$ pada saat surut. Kelimpahan total fitoplankton terendah adalah $4242 \mathrm{Ind} / \mathrm{L}$ saat pasang dan $3242 \mathrm{Ind} / \mathrm{L}$ saat surut, kecerahan saat itu jugarendah yaitu $15-28 \mathrm{~cm}$.Sulardiono et al. (2015), pertumbuhan algae sangat ditentukan oleh badan air. Air yang keruh kurang dapat menjadikan biomas cukup produktif, walaupun perairan itu mempunyai unsur hara yang cukup.

Kecepatan arus saat penelitian berkisar antara 0,07-0,33 m/s. Kecepatan arus saat surut pada titik yang berada di area sungai dan muara yaitu titik I dan II cukup tinggi, serta cukup tenang di titik area pantai yaitu titik III dan IV. Kecepatan arus tersebut dipengaruhi oleh pasang surut dan cuaca atau kecepatan angin saat pengambilan sampel. Hadikusumah (2009), dalam penelitiannya menyatakan bahwa arus dapat dipengaruhi oleh pasang surut serta angin musim.

Salinitas berkisar antara $7-26 \%$ saat pasang dan $4-20 \%$ pada saat surut. Salinitas tiap perairan muara berbeda-beda, tergantung pada masukan air tawar dan perbedaan karakteristik. Sulardiono et al. (2015), pada perairan muara atau estuaria, nilai salinitas cenderung rendah dan semakin ke arah laut terbuka semakin tinggi. Nilai derajad keasaman $(\mathrm{pH})$ selama pengamatan yaitu 6. Nilai tersebut masih tergolong baik. Menurut Odum (1971), perairan dengan $\mathrm{pH}$ antara 6 - 9 merupakan perairan dengan kesuburan tinggi dan tergolong produktif, karena memiliki kisaran $\mathrm{pH}$ yang dapat mendorong proses pembongkaran bahan organik yang ada dalam perairan menjadi mineral-mineral yang dapat diasimilasikan oleh fitoplankton.

Kandungan nitrat yang terukur di lokasi penelitian berkisar antara 0,637 - 0,935 mg/l saat pasang. Saat surut nilai nitrat berkisar antara $0,540-0,935 \mathrm{mg} / \mathrm{l}$. Nilai tersebut tergolong rendah (Oligotrofik). Menurut Effendi (2003), nilai nitrat dapat digunakan untuk mengelompokkan tingkat kesuburan perairan. Perairan dengan kandungan nitrat $0-1 \mathrm{mg} / \mathrm{L}$ dikatakan sebagai perairan oligotrofik. Konsentrasi fosfat di lokasi penelitian berkisar antara 0,06-0,2 mg/l. Nilai tersebut terggolong baik dan sangat baik berdasarkan tingkat kesuburannya. Menurut Hartoko (2010), nilai fosfat 0,051 - 0,100 mg/l tergolong baik dan 0,101 - 0,200 mg/l tergolong sangat baik.

\section{KESIMPULAN}

Berdasarkan hasil penelitian, dapat disimpulkan jenis fitoplankton yang termasuk dalam kelompok HABs yang dominan ditemukan di lokasi penelitian diantaranya, Trichodesmium sp., Skeletonema sp.,Pseudonitzschia sp., dan Ceratium sp.. Sebaran fitoplankton HABs jenis Trichodesmium sp. dengan pola sebaran mengelompok dan Skeletonema sp. dengan pola sebaran seragam terdapat di semua titik sampling baik saat pasang atau surut dengan kelimpahan tertinggi yaitu 785 - $1678 \mathrm{Ind} / \mathrm{L}$ saat pasang dan $764-1168 \mathrm{Ind} / \mathrm{L}$ saat surut, serta 765 1916 Ind/L saat pasang dan 233 - 574 Ind/L saat surut. Ceratium sp. dengan pola sebaran seragam terdapat di titik I dan IV saat pasang, serta terdapat di titik III dan IV saat surut dengan kelimpahan berkisar antara $0-63$ Ind/L saat pasang dan $0-42$ Ind/L saat surut. Pseudonitzschia sp. dengan pola sebaran mengelompok terdapat di semua titik saat pasang sedangkan saat surut terdapat di titik II, III dan IV dengan kelimpahan berkisar antara 0 $191 \mathrm{Ind} / \mathrm{L}$ saat pasang dan $0-84 \mathrm{Ind} / \mathrm{L}$ saat surut.

\section{UCAPAN TERIMAKASIH}

Penulis mengucapkan terimakasih kepadaDr. Ir. Max R. Muskananfola, M.Sc, Ir. Siti Rudiyanti,Msi, Churun Ain, S.Pi, M.Si selaku dosen penguji yang telah bersedia memberikan masukan dan saran. Terima kasih pula penulis ucapkan kepadapihak - pihak yang telah membantu dalam penyusunan penelitian. 


\section{DAFTAR PUSTAKA}

Adnan, Q. 1985. Red Tide. Oseana., 10(2): 48-55.

Aprianti, N.S, B. Sulardiono, M. Nitisupardjo. 2015. Kajian Tentang Fitoplankton yang Berpotensi Sebagai HABs (Harmful Algal Blooms) di Muara Sungai Plumbon Semarang. Diponegoro Journal of Maquares., 4(3): 132-138.

Aunurohim, Dian S. dan Y. Devie. 2008. Fitoplankton Penyebab Harmful Algae Blooms (HABs) di Perairan Sidoarjo. Institut Teknologi Sepuluh November, Surabaya.

Bargu, S, T. Goldstein, K. Roberts, dan F. Gulland. 2012. Pseudonitzschia Blooms, Domoic Acid, and Related California Sea Lion Strandings in Monterey Bay, California. Marine Science., 28(2): 237-253.

Brower, J. S., J. H. Zar and N. O., Ende, 1990. Field and Laboratory Methods for General Ecology. Third Edition. Brown.

Choirun, A, S.H.J Sari dan F. Iranawati. 2015. Identifikasi Spesies Harmful Algae Bloom (HAB) Saat Kondisi Pasang di Perairan Pesisir Brondong, Lamongan, Jawa Timur. Jurnal Ilmu Perikanan dan Kelautan., 25(2): 58-66.

Cokrowati, N, S. Amir, Z. Abidin, B.D.H Setyono dan A. A. Damayanti. 2014. Kelimpahan dan Komposisi Fitoplankton di Perairan Teluk Kodek Pemenang Lombok Utara. Depik., 3(1): 21-26.

Effendi, H. 2003. Telaah Kualitas Air. Kanisius, Yogyakarta, 258 hlm.

Gastrich, M.D. 2000. Harmful Algal Blooms in Coastal Waters of new Jersey. New Jersey Department Of Environmental Protection.

[GEOHAB] Global Ecology and Oceanography of Harmful Algal Blooms. 2001. Science plan. SCOR and IOC, Paris., 87 p.

Hadikusumah. 2009. Karakteristik Gelombang Dan Arus di Eretan, Indramayu. Makara Sains., 13(2): 163-172.

Hart, R.C. danD.W. Peter. 2009. Recent Bloom of The Dinoflagellate Ceratium in Albert Falls Dam (KZN): History, Causes, Spatial Features and Impact on a Reservoir Ecosystem and Its Zooplankton. Water SA., 35(4).

Hartoko, A. 2010. Oseanografi dan Sumberdaya Perikanan - Kelautan di Indonesia. Undip Press, Semarang, 466 hlm.

Isnaini. 2012. Struktur Komunitas Fitoplankton di Perairan Muara Sungai Banyuasin Kabupaten Banyuasin, Sumatera Selatan. Maspari Journal., 4(1): 58-68.

Jannah, R, dan Z. A. Muchlisin. 2012. Komunitas Fitoplankton di Daerah Estuaria Krueng Aceh, Kota Banda Aceh. Depik., 1(3): 189-195.

Khaqiqoh, N.,Pujiono W.P dan Boedi H. 2014. Pola Perubahan Komunitas Fitoplankton di Sungai Banjir Kanal Barat Semarang Berdasarkan Pasang Surut. Diponegoro Journal of Maquares Management of Aquatic Resources, 3 (2): 92-101.

Krebs, C. J. 1989. Ecological Methodology. Harper and Row. New York.

Mulyani, R. Widiarti dan W. Wardhana. 2012. Sebaran Spasial Spesies Harmful Algal Bloom (HAB) di Lokasi Budidaya Kerang Hijau (Perna viridis) Kamal Muara, Jakarta Utara pada Bulan Mei 2011. Jurnal Akuatika., 3(1): 28-39.

Nybakken, J. W. 1992. Biologi Laut Suatu Pendekatan Ekologis. PT Gramedia Pustaka Utama, Jakarta, 459 hlm. (diterjemahkan oleh H. M. Eidman, Koesoebiono, D. G. Bengen, M. Hutomo dan S. Sukardjo).

Odum, E. P. 1971. Fundamentals of Ecology. W.B. Sounders Company Ltd. Philadelphia.

Patty S.I. 2013. Distribusi Suhu, Salinitas dan Oksigen Terlarut di Perairan Kema, Sulawesi Utara. Jurnal Ilmiah Platax., 1(3): 148-157.

Pirzan, A.M, dan P.R.P Masak. 2008. Hubungan Keragaman Fitoplankton dengan Kualitas Air di Pulau Bauluang, Kabupaten Takalar, Sulawesi Selatan. Biodiversitas., 9(3): 217-221.

Sachlan, M. 1982. Planktonologi. Fakultas Perikanan dan Ilmu Kelautan Universitas Diponegoro, Semarang, 269 hlm. 
Sediadi, A.2004. Dominasi Cyanobacteria pada Musim Peralihan di Perairan Laut Banda dan Sekitarnya. Jurnal Makara Sains, 7 (1) :1-14.

Sulardiono, B., S. Hutabarat dan A. Djunaedi. 2015. Buku Ajar Planktonologi. Universitan Diponegoro, Semarang, $117 \mathrm{hlm}$.

Thoha, H. 2004. Kelimpahan Plankton di Perairan Bangka Belitung da Laut Cina Selatan, Sumatera, Mei - Juni 2002. Makara Sains., 8(3): 96-103

Wiadnyana, N.N. 1996. Mikroalga Berbahaya di Perairan Indonesia. Oseanologi dan Limnologi di Indonesia, Puslitbang Oseanologi LIPI, 29: 15-28.

Wulandari, Sri.Y. 2012. Status Perairan Banjir Kanal Timur Semarang Ditinjau dari Kadar Logam Berat Chromium dalam Air, Sedimen, dan Jaringan Lunak Kerang Darah. Buletin Oseanografi Marina., 1:1-7.

Yuliana. 2015. Distribusi dan Struktur Komunitas Fitoplankton di Perairan Jailolo, Halmahera Barat. Jurnal Akuatika., 6(1): 4-48. 